\title{
Repair of incarcerated inguinal hernia in an infant with acute viral bronchiolitis
}

\author{
[La réparation d'une hernie inguinale incarcérée chez un enfant atteint d'une \\ bronchiolite virale aigue]]
}

Robin G. COx MB BS MRCP (UK) FRCA FRCPC

Purpose: To describe the anesthetic concerns and management options in an infant with acute viral bronchiolitis who required emergency surgery.

Clinical features: A 12-week-old infant presented to the emergency department with an incarcerated right inguinal hernia. The history was complicated by concurrent acute bronchiolitis. As the hernia was irreducible, emergency surgery was required. General endotracheal anesthesia, following a rapid sequence induction, was supplemented with a caudal epidural block. Inhaled salbutamol and suctioning for thick tracheal secretions were required and were found to be clinically useful. The baby made a good postoperative recovery.

Conclusions: A variety of techniques may be used to anesthetize the infant with concurrent acute bronchiolitis. In this case a good outcome was achieved with combined general and regional anesthesia, together with the use of inhaled salbutamol.

Objectif : Décrire les problèmes anesthésiques et les solutions possibles entourant le cas d'un enfant atteint de bronchiolite virale aiguë qui doit être opéré d'urgence.

Éléments cliniques : Un bébé de 12 sem, amené à l'urgence, présentait une hernie inguinale droite incarcérée qui nécessitait une opération d'urgence. Le portrait clinique se compliquait d'une bronchiolite aiguë. L'anesthésie endotrachéale générale, réalisée à la suite d'une séquence d'induction rapide, a été complétée par un bloc péridural caudal. L'inhalation de salbutamol et l'aspiration de sécrétions trachéales épaisses ont été nécessaires et utiles. Le bébé s'est très bien rétabli de l'opération.

Conclusion : Diverses techniques anesthésiques peuvent être utiles dans le cas d'un bébé atteint de bronchiolite aiguë concomitante. De bons résultats ont été obtenus en combinant l'anesthésie générale et régionale avec l'inhalation de salbutamol.
A CUTE viral bronchiolitis is a common respiratory infection in infants. The causal agent is nearly always the respiratory syncytial virus (RSV). It is estimated that approximately $1 \%$ of infants with RSV infection will require hospitalization and that these account for more than 125,000 admissions per annum in the United States. ${ }^{1}$ The clinical features of RSV bronchiolitis are those of an acute viral illness, characterized by wheezing and respiratory distress. The recovery period may be quite prolonged and residual airway reactivity may persist for months or even years after an infection. ${ }^{2}$

In infants in the acute phase of RSV bronchiolitis who require elective surgery, the operation is generally postponed until the infection has resolved. The exact period required before anesthesia can be undertaken is unclear and will depend on many factors, including the urgency of the surgery. Occasionally an infant with active bronchiolitis will present for emergency surgery and some form of anesthesia will be required.

A case is presented of a 12-week-old baby with moderately severe bronchiolitis, who presented with an incarcerated inguinal hernia. Options for anesthesia are presented and the topic of RSV infection and anesthesia is discussed.

\section{Case report}

The infant was a $5.1-\mathrm{kg}$ male, born at 37 weeks postconceptual age. There were no neonatal concerns and he was quite well until the age of 12 weeks. At this time, five days prior to admission, he developed a fever, runny nose and congested cough. He was medicated with acetaminophen at home. On the day of presentation the

From the Division of Pediatric Anesthesia, Alberta Children's Hospital, University of Calgary, Calgary, Alberta, Canada. Address correspondence to: Dr. Robin G. Cox, Division of Pediatric Anesthesia, Alberta Children's Hospital, 1820 Richmond Road S.W.,

Calgary, Alberta T2T 5C7, Canada. Phone: 403-943-7260; Fax: 403-943-7606; E-mail: robin.cox@calgaryhealthregion.ca Accepted for publication May 29, 2003.

Revision accepted October 22, 2003 
baby was noted to be very irritable with an increased cough and long periods of crying. Two hours prior to admission, the parents noticed a scrotal swelling. There was no history of vomiting and the baby had breast fed around the time that the swelling was seen. The baby was taken to the emergency department and found to have a right sided incarcerated inguinal hernia.

Vital signs included a heart rate of 140 beats. $\mathrm{min}^{-1}$, a respiratory rate of 36 breaths $\mathrm{min}^{-1}$, a temperature of $37.4^{\circ} \mathrm{C}$ (after acetaminophen) and a hemoglobin oxygen saturation $\left(\mathrm{SpO}_{2}\right)$ of $92 \%$ in room air. Physical examination revealed an irritable baby with nasal congestion, a cough typical of bronchiolitis, intercostal indrawing with bilateral crackles and wheezes audible over both lung fields.

Several attempts were made by both the emergency physician and the pediatric surgeon to reduce the hernia, including sedation with nasal midazolam 0.2 $\mathrm{mg} \cdot \mathrm{kg}^{-1}$. As reduction was unsuccessful, and there was increasing concern about the circulation to both bowel and testis, it was decided to explore the hernia surgically on an emergency basis.

In the immediate preoperative period, the heart rate was 150 beats. $\mathrm{min}^{-1}$ and the respiratory rate had climbed to 64 breaths. $\mathrm{min}^{-1}$. This was despite the child being still sedated with midazolam and in no obvious pain. The physical signs were otherwise unchanged. As the diagnosis of viral bronchiolitis was unambiguous clinically and there were no features to suggest bacterial infection or systemic sepsis, additional investigations were not requested. At this time, the baby had been nil-by-mouth for four hours following the breast milk feed.

Following application of routine monitors and preoxygenation, a rapid sequence induction was carried out with atropine $0.02 \mathrm{mg} \cdot \mathrm{kg}^{-1}$, propofol $4 \mathrm{mg} \cdot \mathrm{kg}^{-1}$ and succinylcholine $2 \mathrm{mg} \cdot \mathrm{kg}^{-1}$. Cricoid pressure was applied and endotracheal intubation with a $3.5-\mathrm{mm}$ uncuffed tracheal tube was performed without difficulty. A slight air leak was noted around the tube with positive pressure. Anesthesia was then maintained with oxygen, nitrous oxide and sevoflurane. $\mathrm{An}_{\mathrm{FIO}}$ of 0.45 was required to maintain $\mathrm{SpO}_{2}$ values of 96 to $98 \%$. The lungs were ventilated mechanically with a DatexOhmeda S/5 anesthesia delivery unit. Pressure controlled ventilation with a rate of 15 breaths. $\mathrm{min}^{-1}$, pressures of $20 / 2 \mathrm{~cm} \mathrm{H}_{2} 0$ and an I:E ratio of 2:1, produced an end-tidal $\mathrm{CO}_{2}$ value of 38 to $43 \mathrm{mmHg}$. As the baby appeared to be relatively easy to ventilate and there was no hemodynamic instability, we did not place an arterial catheter.

Several minutes following induction, the baby experienced an episode of violent coughing on the endotracheal tube, and the $\mathrm{SpO}_{2}$ fell to $85 \%$. This episode responded quickly to both deepening of the anesthetic with sevoflurane and propofol $2 \mathrm{mg} \cdot \mathrm{kg}^{-1}$, and to nebulized salbutamol $(100 \mu \mathrm{g})$ via the endotracheal tube. This episode of coughing did not recur, but on two subsequent occasions a small dose of mivacurium $\left(0.1-0.2 \mathrm{mg} \cdot \mathrm{kg}^{-1}\right)$ was given to facilitate positive pressure ventilation.

The surgical procedure was conducted uneventfully. The incarcerated bowel, though congested, was felt to be viable, as was the testis. Surgical and postoperative analgesia was accomplished with a caudal epidural block, using $5 \mathrm{~mL} 0.25 \%$ bupivacaine with epinephrine 1:200,000. Caudal anesthesia was felt to be safe as there were no signs of systemic sepsis or bacterial infection.

At the end of surgery the baby was placed on 100\% oxygen and allowed to awaken prior to extubation. A second dose of inhaled salbutamol $(100 \mu \mathrm{g})$ was given as a prophylactic measure and the endotracheal tube was suctioned for copious amounts of thick white secretions. Once the baby was wide awake and breathing well, extubation was carried out without any difficulty. The baby was observed in the recovery room and remained stable. The $\mathrm{SpO}_{2}$ in room air was $90 \%$, which increased to $100 \%$ with oxygen via nasal prongs at $0.5 \mathrm{~L} \cdot \mathrm{min}^{-1}$. Following transfer to the ward, $\mathrm{SpO}_{2}$ monitoring was continued and the oxygen requirement gradually decreased. He remained hemodynamically stable and afebrile (with acetaminophen). By the ninth postoperative hour, the baby demonstrated $\mathrm{SpO}_{2}$ readings in the 97 to $99 \%$ range in room air. At the time of discharge from hospital, after only one postoperative day, the baby was stable, pain-free and had an $\mathrm{SpO}_{2}$ of $99 \%$ in room air. He made a subsequent uneventful recovery.

\section{Discussion}

Although viral bronchiolitis is a relatively common disease, the need to perform surgery during the acute phase of the illness is very unusual. A PubMed search using the terms "bronchiolitis" and "anesthesia" as well as several permutations, failed to reveal any case reports of anesthesia in this situation. An informal poll of the 11 pediatric anesthesiologists at the Alberta Childrens Hospital, Calgary, who have been in practice for a total duration of 135 years, was carried out; no-one could recollect the same scenario in an infant. With elective cases, the consensus is to postpone surgery until the child has fully recovered from the infection. This seems to be particularly important in the case of complex procedures, such as open heart surgery and major airway reconstruction. ${ }^{3-5}$ The exact 
period that surgery must be postponed must take into account the nature and urgency of the surgery, any other comorbidities and the presence of any ongoing symptoms or abnormal physical signs.

It has been shown that the effects of bronchiolitis may persist for a prolonged period after the attack. Kneyber showed that children continue to wheeze after RSV bronchiolitis in the first year of life and wheezing may persist for up to five years of followup. ${ }^{2}$ Clearly it is not feasible to postpone surgery indefinitely, so the anesthesiologist must accept that a child with a history of bronchiolitis in the past five years may still be prone to wheezing.

If anesthesia is required on an emergency basis, when the infant is still in the acute phase of bronchiolitis, this presents a major challenge to the anesthesiologist. If a local or regional anesthetic technique is feasible, this may have significant advantages. Spinal ${ }^{6}$ or caudal $^{7}$ anesthesia are accepted techniques for inguinal hernia repair in infants and regional anesthesia was seriously considered for the patient presented. Even in older children it is possible to perform significant surgery under regional anesthesia. For example, Kuwahara and Goresky describe appendectomy under epidural anesthesia in a 13-yr-old boy with severe asthma. ${ }^{8}$ In this case, however, the surgeon was concerned about the possibility of bowel ischemia, and could not predict the duration of the case, should bowel resection have been required. Furthermore the child had only just met the fasting guidelines for elective surgery (four hours following a breast feed). The effects of pain and sedative medication might have delayed gastric emptying, leading us to choose a general anesthetic technique with endotracheal intubation.

General anesthesia in the presence of acute bronchiolitis carries certain risks, the greatest of which is exacerbation of airway reactivity. Agents that suppress airway reflexes, e.g., propofol, would seem to have an advantage. Sevoflurane, being less irritant to the airway than isoflurane or desflurane, would also be a logical choice. For many years, halothane was felt to be useful in cases of increased airway reactivity, however sevoflurane has been shown also to have a very favourable profile in terms of upper airway reactivity and has the added advantages of rapid recovery and less myocardial depression compared with halothane. ${ }^{9,10}$ Despite the use of propofol and sevoflurane, the infant did experience an episode of violent coughing on the endotracheal tube that could only be broken by deepening the anesthetic with propofol and sevoflurane. Studies of children with upper respiratory infections have suggested a possible advantage of the laryngeal mask airway ${ }^{11}$ over endotracheal intubation, however this may not apply to the infant with bronchiolitis. Moreover, in this case, the laryngeal mask airway was not felt to be an option, due to the risk of aspiration.

Certain other adjuncts may be useful intraoperatively in the patient with bronchiolitis. The use of bronchodilators has been evaluated in a meta-analysis of 15 studies by Kellner et al., which concluded that "bronchodilators produce modest short-term improvement in clinical features of mild or moderately severe bronchiolitis". ${ }^{12}$ A subsequently published, but smaller meta-analysis, observed that "conclusive evidence for the efficacy of $\beta_{2}$-agonist therapy for bronchiolitis remains unavailable". ${ }^{13}$ How relevant these conclusions are to the anesthetized, intubated infant is unclear. Given the relatively safe profile of inhaled salbutamol, it would seem reasonable to attempt a trial of this therapy perioperatively and continue if there is a favourable clinical response. It may be that the choice of inhaled bronchodilator is of importance. Sanchez, for example, demonstrated the superiority of racemic epinephrine over salbutamol, both in terms of clinical score and pulmonary mechanics. ${ }^{14}$

Once endotracheal intubation has been accomplished, appropriate ventilation must be provided. After an initial period of manual ventilation, when the airway pressures, breath sounds and chest wall excursion are assessed, the patient may be placed on mechanical ventilation. There may be a need to suction thick, copious secretions from the endotracheal tube. Experience with the mechanical ventilation of infants in respiratory failure from bronchiolitis suggests that ventilation should be tailored to minimize overdistention and prevent volutrauma. ${ }^{15}$ Adequate oxygenation is the goal, although some degree of permissive hypercapnea may help to minimize overdistention. In critically ill infants with severe bronchiolitis, high-frequency ventilation and even extracorporeal membrane oxygenation have been used successfully. ${ }^{15}$

Other specific therapies for bronchiolitis are of limited, if any, benefit. It has not been possible to show a consistent benefit of corticosteroids on the clinical course of bronchiolitis. ${ }^{16}$ The use of the antiviral agent, ribavarin, has become difficult to justify, due to its high cost and inconsistent reports of efficacy. ${ }^{16}$ Antibiotics, although commonly used in the hospitalized infant with bronchiolitis, are unlikely to have a therapeutic value. ${ }^{16}$ Preventative measures are of more interest. The surgical infant facing major cardiac or airway reconstructive surgery may be screened for RSV and surgery postponed in the face of a positive test. ${ }^{3-5}$ There is no benefit, however, in conducting routine RSV testing for less complex surgery in asymptomatic patients. ${ }^{17}$ High risk infants may be protected during the RSV season with 
palivizumab, a form of passive immunoprophylaxis. This protection appears to be effective, although the costs are significant. ${ }^{18}$

Apnea is a well recognized complication of RSV bronchiolitis, ${ }^{19}$ even in infants with mild respiratory symptoms. Following general anesthesia, therefore, it would be wise to monitor these patients closely. Pulse oximetry may be useful as oxygen needs may fluctuate during this period. One other rare complication of RSV infection of concern to the anesthesiologist is myocarditis. This may be manifested by heart block ${ }^{20}$ or myocardial dysfunction with dysrythmias. ${ }^{21}$

In summary, the need to provide anesthesia for an infant during an attack of moderate or severe bronchiolitis, fortunately, is rare. Regional anesthesia may have advantages, although this is not always a viable option. If general anesthesia is required, agents that produce minimal airway irritation are advised and a trial of $\beta_{2}$-agonist therapy is worthwhile. In the postoperative period, oxygen requirements may vary and apnea may be a risk, therefore monitoring with continuous pulse oximetry is recommended for a minimum of $24 \mathrm{hr}$ and for longer if there is an ongoing oxygen requirement or respiratory compromise.

\section{References}

1 Panitch HB. Bronchiolitis in infants. Curr Opin Pediatr 2001; 13: 256-60.

2 Kneyber MC, Steyerberg EW, de Groot R, Moll HA. Long-term effects of respiratory syncytial virus (RSV) bronchiolitis in infants and young children: a quantitative review. Acta Paediatr 2000; 89: 654-60.

3 Khongphatthanayothin A, Wong PC, Samara $\Upsilon$, et al. Impact of respiratory syncytial virus infection on surgery for congenital heart disease: postoperative course and outcome. Crit Care Med 1999; 27: 1974-81.

4 Altman CA, Englund JA, Demmler G, et al. Respiratory syncytial virus in patients with congenital heart disease: a contemporary look at epidemiology and success of preoperative screening. Pediatr Cardiol 2000; $21: 433-8$.

5 Ludemann JP, Hughes CA, Noah Z, Holinger LD. Complications of pediatric laryngotracheal reconstruction: prevention strategies. Ann Otol Rhinol Laryngol 1999; 108: 1019-26.

6 Shenkman Z, Hoppenstein D, Litmanowitz I, et al. Spinal anesthesia in 62 premature, former-premature or young infants-technical aspects and pitfalls. Can J Anesth 2002; 49: 262-9.

7 Gunter JB, Watcha MF, Forestner JE, et al. Caudal epidural anesthesia in conscious premature and highrisk infants. J Pediatr Surg 1991; 26: 9-14.
8 Kuwahara B, Goresky GV. Anaesthetic management of an asthmatic child for appendicectomy. Can J Anaesth 1994; 41: 523-6.

9 Lerman J, Davis PJ, Welborn LG, et al. Induction, recovery, and safety characteristics of sevoflurane in children undergoing ambulatory surgery. A comparison with halothane. Anesthesiology 1996; 84: 1332-40.

10 Wodey E, Pladys P, Copin C, et al. Comparative hemodynamic depression of sevoflurane versus halothane in infants. An echocardiographic study. Anesthesiology 1997; 87: 795-800.

11 Tait AR, Pandit UA, Voepel-Lewis T, Munro HM, Malviya $S$. Use of the laryngeal mask airway in children with upper respiratory tract infections: a comparison with endotracheal intubation. Anesth Analg 1998; 86: 706-11.

12 Kellner JD, Ohlsson A, Gadomski AM, Wang EE. Efficacy of bronchodilator therapy in bronchiolitis. A meta-analysis. Arch Pediatr Adolesc Med 1996; 150: 1166-72.

13 Flores $G$, Horwitz RI. Efficacy of $\beta_{2}$-agonists in bronchiolitis: a reappraisal and meta-analysis. Pediatrics 1997; 100: 233-9.

14 Sanchez I, De Koster J, Powell RE, Wolstein R, Chernick $V$. Effect of racemic epinephrine and salbutamol on clinical score and pulmonary mechanics in infants with bronchiolitis. J Pediatr 1993; 122: 145-51.

15 Swift JD, Goodman G. Respiratory syncytial virus bronchiolitis. In: Levin DL, Morriss FC (Eds.). Essentials of Pediatric Intensive Care, 2nd ed. New York: Churchill Livingstone Inc.; 1997: 432-6.

16 Meissner HC. Uncertainty in the management of viral lower respiratory tract disease. Pediatrics 2001; 108: 1000-3.

17 Manworren R, Conner C, Myers M, McCarthy K. Clinical impact of preoperative respiratory syncytial virus testing. AORN J 1999; 69: 1003-13.

18 Paes $B A$. Current strategies in the prevention of respiratory syncytial virus disease. Paediatr Respir Rev 2003; 4: 21-7.

19 Anas N, Boettrich C, Hall CB, Brooks JG. The association of apnea and respiratory syncytial virus infection in infants. J Pediatr 1982; 101: 65-8.

20 Bairan AC, Cherry JD, Fagan LF, Codd JE Jr. Complete heart block and respiratory syncytial virus infection. Am J Dis Child 1974; 127: 264-5.

21 Thomas JA, Raroque S, Scott WA, Toro-Figueroa LO, Levin DL. Successful treatment of severe dysrhythmias in infants with respiratory syncytial virus infections: two cases and a literature review. Crit Care Med 1997; 25: 880-6. 